to penetrate the "dim and distant future." My descriptions of the older Archrean rocks and their distribution are not materially affected by the theory of mechanical metamorphism; but we must of course cease to construct time-series out of them. Alas! how many a stately time-edifice goes down before the blows of those gods of the hammer, Lehmann and Lapworth!

Ch. Callaway.

\title{
THE SERPENTINE OF THE LIZARD.
}

Sir,-Would you kindly allow me to reply to the letter of Prof. Bonney in your January issue on the above subject regarding my alleged "two slight errors."

1. I think the Professor's mind has very naturally (perbaps without reference to the map) reverted to the south end of the Pentreath Beach, where the hornblende schist occurs in conjunction with the serpentine, which he has so ably and minutely described; but the dyke in question is at the north, or Kynance end, near a large exposure of banded gneissic rocks forming the foreshore of Holestrow, similar to what occurs in many other localities described by the Professor as "granulitic," as at Caerleon and Kennack, at the west end of which latter Cove the dykes cutting the serpentine are seen to coalesce with the "granulitic" rocks forming the foreshore.

2. For my own part I know of no "granulitic group" in the whole area with igneous rocks involved or included in it, but a group of rocks to which the term "granulitic" might be applied, which every evidence seems to point at as having a coinmon igneous origin, although differing widely from each other; neither do I know any separation between these and the hornblende schists save in the extremes of their compositions, both of which are frequently mingled together in the same dykes.

I quite agree and deeply feel with Prof. Bonney the very great difficulties connected with some of these Lizard rocks, such as the explanation of the banded gneissic series which has been so philosophically dealt with by Mr. Teall; and it was for this very reason that I ventured my short communication on the dyke and its lessons, in the hope that it might throw some little additional light on these gneissic and other rocks, which I have always regarded as presenting very much that is problematic.

Alex. Somervall.

59, Fleet Street, Torquay, Jan. 9th, 1889.

\section{MISCEI工AINEOUS.}

Adnenda.- In the section illustrating Prof. Hughes' paper, Geol. MAG. Jan. 1889 , p. 9, the asterisk indicating the third fossil locality mentioned in the text has been omitted. The spot referred to is immediately under the Bronllwyd Grit, vertically below the $Y$ of that word on the diagram. 